\title{
Chemical Profiling and Antimicrobial Properties of Honey Bee (Apis mellifera L.) Venom
}

\author{
Irina Tanuwidjaja ${ }^{1}$, Lidija Svečnjak ${ }^{2, *}$, Domenika Gugić ${ }^{1}\left(\mathbb{D}\right.$, Marko Levanić $^{2}$, Slaven Jurić ${ }^{3} \mathbb{D}$, \\ Marko Vinceković ${ }^{3}$ and Mirna Mrkonjić Fuka ${ }^{1}$ \\ 1 Department of Microbiology, Faculty of Agriculture, University of Zagreb, 10000 Zagreb, Croatia; \\ ianuwidjaja@agr.hr (I.T.); domenika.gugic@gmail.com (D.G.); mfuka@agr.hr (M.M.F.) \\ 2 Department of Fisheries, Apiculture, Wildlife Management and Special Zoology, \\ Faculty of Agriculture, University of Zagreb, 10000 Zagreb, Croatia; markolevanic95@gmail.com \\ 3 Department of Chemistry, Faculty of Agriculture, University of Zagreb, 10000 Zagreb, Croatia; \\ sjuric@agr.hr (S.J.); mvincekovic@agr.hr (M.V.) \\ * Correspondence: lsvecnjak@agr.hr; Tel.: +385-(0)1-239-3995
}

check for updates

Citation: Tanuwidjaja, I.; Svečnjak, L.; Gugić, D.; Levanić, M.; Jurić, S.; Vinceković, M.; Mrkonjić Fuka, M. Chemical Profiling and Antimicrobial Properties of Honey Bee (Apis mellifera L.) Venom. Molecules 2021, 26, 3049. https://doi.org/10.3390/ molecules26103049

Academic Editors: Nada Orsolic and Maja Jazvinšćak Jembrek

\section{Received: 30 April 2021}

Accepted: 17 May 2021

Published: 20 May 2021

Publisher's Note: MDPI stays neutral with regard to jurisdictional claims in published maps and institutional affiliations.

Copyright: (C) 2021 by the authors. Licensee MDPI, Basel, Switzerland. This article is an open access article distributed under the terms and conditions of the Creative Commons Attribution (CC BY) license (https:/ / creativecommons.org/licenses/by/ $4.0 /)$.

\begin{abstract}
The incidence of antibiotic resistance in pathogenic bacteria has become an alarming clinical and social problem. Therefore, the demand for alternative antimicrobial compounds has increased. In this study, a chemical profile of honey bee (Apis mellifera L.) venom (HBV) has been determined by HPLC and FTIR-ATR spectroscopy, and tested for antibacterial activity, as well as efficiency with regard to conventional antibiotics. The investigated HBV was of high quality with melittin and total protein contents of $70.10 \pm 7.01 \%$, and $84.44 \pm 3.12 \mathrm{~g} / 100 \mathrm{~g}$, respectively. The purity of HBV was confirmed by FTIR-ATR spectral profiling, which revealed a unique pattern of absorption bands that are characteristic of its major fractions. In addition, HBV showed a broad spectrum of activity against all three tested biomasses of potentially pathogenic Gram-positive and Gram-negative bacteria with MIC values ranging between 12.5 and $200 \mu \mathrm{g} / \mathrm{mL}$, and MBC between 12.5 and $400 \mu \mathrm{g} / \mathrm{mL}$. When compared to conventional antibiotics, HBV $(400 \mu \mathrm{g})$ showed up to $27.8 \%$ efficiency of tetracycline $(30 \mu \mathrm{g}), 52.2 \%$ erythromycin $(15 \mu \mathrm{g}), 21.2 \%$ ciprofloxacin $(5 \mu \mathrm{g})$, and $34.6 \%$ of ampicillin-sulbactam $(20 \mu \mathrm{g})$. The overall results demonstrate the therapeutic potential of the analyzed HBV.
\end{abstract}

Keywords: honey bee venom; melittin; total protein; FTIR-ATR spectral profile; antibacterial activity; conventional antibiotics

\section{Introduction}

Since the discovery of antibiotics, their uncritical application and overuse have led to the development of antimicrobial drug resistance in numerous bacterial pathogens. Such bacteria are becoming a serious clinical and social problem throughout the world. Thus, new effective antibacterial agents with a novel mode of action need to be developed [1]. Antimicrobial peptides (AMPs), the defense peptides found in different hosts, are one such attractive therapeutic candidate which can kill a broad range of bacteria by disrupting their membranes. In addition, bacteria do not tend to develop drug resistance to AMPs [2,3].

Natural products such as venoms from different animals (e.g., bees, wasps, snakes, and scorpions) are an important source of such new bioactive peptides [4,5] and promising antimicrobial agents against various microbial pathogens [5,6]. Honey bee (Apis mellifera L.) venom (HBV), secreted in honey bee workers' venom glands as a protection mechanism, has long been used to treat an array of medical conditions $[7,8]$. It is a complex mixture of substances (primarily polypeptides and enzymes) exhibiting a wide range of biological activities, including antimicrobial, cytotoxic, hemolytic and anti-inflammatory activity [9-12]. Generally, the biological activity of HBV stems from peptides (melittin, apamin, adolapin, the mast cell degranulating peptide, secapin, procamine, protease inhibitor, tertiapin, and other small peptides), enzymes (phospholipase A2 (PLA2), phospholipase B, hyaluronidase, 
phosphatase, $\alpha$-glucosidase, acid phosphomonoesterase, and lysophospholipase), amines (histamine, dopamine, and noradrenaline), amino acids (aminobutyric acid and $\alpha$-amino acids), sugars (glucose and fructose), phospholipids, and volatile compounds [13-16]. However, the purity and composition of HBV, as well as the concentration of its substances, differ significantly $[17,18]$.

The major compound and the principal bioactive peptide with antimicrobial activity in HBV is mellitin, which comprises up to $60 \%$ of the dry HBV weight [19]. The antimicrobial activity of pure mellitin or natural HBV mix, against several Gram-positive and Gram-negative bacteria, is well documented and the effect varies with different HBV or different species applied [11,20-22]. Although the effect of any antimicrobial compound is dependent on the initial microbial density (cells per volume unit), the majority of studies primarily focus on testing the effect of HBV on a single microbial biomass. For example, it is well-known, for antibiotics, that the relative amount of drug needed to inhibit the growth of a bacterial population increases with the density of that population and, for some antibiotics, the minimum inhibitory concentration (MIC) changes with the density of bacteria exposed $[23,24]$. In addition, depending on the microorganism whose antimicrobial susceptibility is tested, different antibiotic concentrations are used. In addition, considering the increasing prevalence and complexity of antimicrobial resistance mechanisms, the guidelines for antimicrobial susceptibility testing are prone to modifications due to the changes in MIC breakpoints and the detection of new resistance mechanisms $[25,26]$.

Therefore, the objective of this study was to evaluate the antibacterial activity of honey bee venom against three different biomass quantities $(3,6$ and $8 \log$ CFU / mL) of selected potentially pathogenic Gram-positive (Staphylococcus aureus, Listeria innocua, and Bacillus cereus), and Gram-negative (Escherichia coli and Salmonella enterica) bacteria by determining the minimum inhibitory (MIC) and bactericidal (MBC) concentrations, and compare it with the conventional antibiotics. In addition, we aimed to determine the quality and purity of the HBV sample prior to microbiological assay by performing a detailed chemical profiling using classical, chromatographic and spectroscopic analytical methods.

\section{Results and Discussion}

\subsection{Honey Bee Venom Composition}

The results of HPLC analysis and the Kjeldahl method confirmed the good quality of the investigated HBV sample, where the melittin and total protein contents were $70.10 \pm 7.01 \%$, and $84.44 \pm 3.12 \mathrm{~g} / 100 \mathrm{~g}$, respectively. Compared to most of the reports on the $\mathrm{HBV}$, where the melittin content ranged from 40 to $60 \%[8,19,27,28]$, with an average of $50 \%$, and the total protein content from $47.2 \%$ to $77.8 \%$ [29-31], the analyzed sample showed above-average high-quality properties.

Melittin and phospholipase A2 (PLA2) are not only the most abundant and the most studied compounds of honey bee venom [8]; they are also considered to be responsible for most of the beneficial effects of venom [16], including the antimicrobial activity against various microorganisms [32-35]. The quantitative analyses of selected bee venom components (e.g., melittin, dopamine, and histamine) have been an indirect means of measuring its purity and quality, especially given that the quality can be strongly affected by the venom storage, which may cause degradation of the venom components (e.g., by autolysis due to presence of proteases in the venom) [36]. The purity of bee venom is, nowadays, mostly determined based on the melittin content.

\subsection{Spectral Assignment of Molecular Vibrations Observed in Bee Venom Powder/FTIR-ATR Spectral Profiling}

The results of the spectral analysis revealed a characteristic FTIR-ATR spectrum of honey bee venom powder distinguished by a unique pattern of absorption bands primarily arising from molecular vibrations related to the structure of honey bee venom's major fractions-peptides and proteins (Figure 1). Given that dried honey bee venom represents a complex biological mixture of various polymeric macromolecules with predominant 
peptide and protein (enzyme) constituents, such as the most abundant 26-amino-acid polypeptide melittin (comprising 40-60\% of the dry weight of bee venom) and PLA2 $(\sim 10-12 \%)[15,27,37]$, the absorption bands of these macromolecules predominate in its IR spectrum. As presented in Figure 1, the FTIR-ATR spectrum of HBV powder is characterized by a broad medium-intensity absorption band observed in the spectral range from 3500 to $3100 \mathrm{~cm}^{-1}$ (with an absorption maximum at $3288 \mathrm{~cm}^{-1}$ ), which is assigned to the $\mathrm{N}-\mathrm{H}$ stretching vibrations (amide A band) of the peptide and protein secondary structures [38,39], while low-intensity signal belonging to the same vibrational mode appears at $3060 \mathrm{~cm}^{-1}$ (amide B). The latter may also indicate an overtone of the amide II band [38]. Medium intensity absorptions observed at $2960 \mathrm{~cm}^{-1}$ and $2928 \mathrm{~cm}^{-1}$ correspond to $\mathrm{CH}_{2}$ asymmetric stretching vibrations, and they are followed by the lower intensity analyte signals at $2873 \mathrm{~cm}^{-1}$ and $2855 \mathrm{~cm}^{-1}$ that are attributed to $\mathrm{CH}_{2}$ symmetric stretchings.

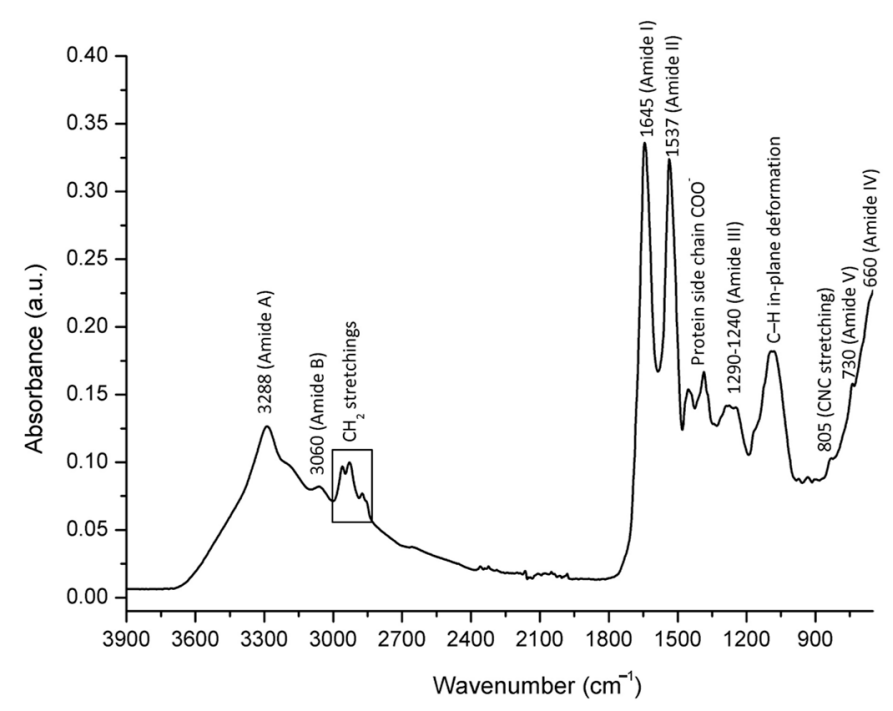

Figure 1. Characteristic FTIR-ATR spectrum of dried honey bee venom (powder) with the assignation of major underlying molecular vibrations.

The spectral region between 1700 and $700 \mathrm{~cm}^{-1}$ (fingerprint region) is populated by a series of absorption bands that are unique to the peptide/protein secondary structure. The most prominent vibrations in this region, occurring at $1645 \mathrm{~cm}^{-1}$ and $1537 \mathrm{~cm}^{-1}$, are assigned to the amide I ( $\mathrm{C}=\mathrm{O}$ stretching) and amide II $(\mathrm{N}-\mathrm{H}$ bending and $\mathrm{C}-\mathrm{N}$ stretching vibrations) bands, respectively. This is in compliance with the report on the basic spectral features of the bee venom provided by Park et al. [40]. Other amide bands are represented in the following frequencies: The peaks arising at 1454 and $1386 \mathrm{~cm}^{-1}$ are likely to result from the protein side chain $\mathrm{COO}^{-}$. A broad medium intensity absorption occurs between 1290 and $1240 \mathrm{~cm}^{-1}$ due to the amide III band, which comprises 30\% of C-N stretching, 30\% of $\mathrm{N}-\mathrm{H}$ bending, $10 \%$ of $\mathrm{C}-\mathrm{O}$ stretching, and $10 \%$ of $\mathrm{O}=\mathrm{C}-\mathrm{N}$ bending vibrations, while the rest belongs to other vibrations [38]. A medium intensity absorption observed at $1088 \mathrm{~cm}^{-1}$ can be attributed to the $\mathrm{C}-\mathrm{H}$ in-plane deformation vibration of various aromatic structures in the bee venom. A weak analyte signal occurs nearby at $805 \mathrm{~cm}^{-1}$ due to the symmetric $\mathrm{CNC}$ stretching vibration of proteins (enzymes). Amide IV (primarily $\mathrm{O}=\mathrm{C}-\mathrm{N}$ bending) and amide $\mathrm{V}$ (N-H bending) bands have been observed at $660 \mathrm{~cm}^{-1}$ and $730 \mathrm{~cm}^{-1}$, respectively.

Figure 2 shows comparative spectral features of the investigated HBV powder vs. genuine liquid bee venom extracted from a 24-day old honey bee. The results have revealed similar integral spectral features of dried and liquid venom with differences exhibited in the relative absorption intensities of water and peptide/protein bands. These effects were reflected in the lower absorption intensities of the $\mathrm{O}-\mathrm{H}$ stretching vibrations of water (intense absorption in the $3700-3000 \mathrm{~cm}^{-1}$ region) in the dried form of HBV compared to a liquid form of genuine bee venom, and an overlapping of the $\mathrm{H}-\mathrm{O}-\mathrm{H}$ deformation of water with 
the amide I band at $1645 \mathrm{~cm}^{-1}$. This was followed by higher absorption intensities of the analyte signals of other peptide/protein-based venom components observed in dried HBV. Given that no analyte signals other than those specific for HBV proteins were observed, these results confirmed the purity of dried bee venom used for the microbiological assay.

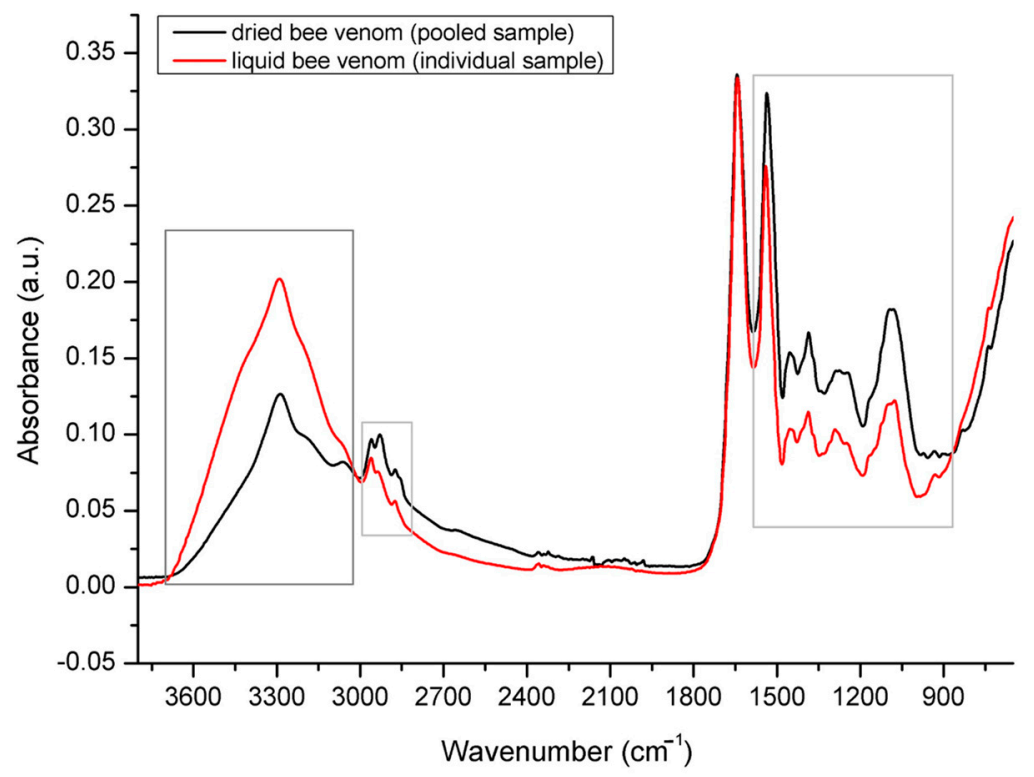

Figure 2. Comparative spectral features of dried vs. liquid honey bee venom (extracted from a 24-day old worker bee).

\subsection{Antibacterial Activity of Honey Bee Venom (HBV)}

The antibacterial activity of $\mathrm{HBV}$ was determined by evaluating minimum inhibitory (MIC) and minimum bactericidal (MBC) concentrations against different biomass quantities $(3,6$, and $8 \log \mathrm{CFU} / \mathrm{mL})$ of selected Gram-positive and Gram-negative bacteria. The MIC values were calculated as the concentrations that inhibited more than $95 \%$, and $\mathrm{MBC}$ more than $99 \%$, of bacterial growth. The results are summarized in Table 1.

Table 1. Minimum inhibitory (MIC) and minimum bactericidal (MBC) concentrations against different biomass quantities of selected bacterial strains.

\begin{tabular}{cccc}
\hline \multirow{2}{*}{ Bacterial Strains } & \multicolumn{3}{c}{ MIC/MBC $[\boldsymbol{\mu g} / \mathbf{m L}]$} \\
\cline { 2 - 4 } & $\mathbf{3} \log$ CFU/mL & $\mathbf{6} \log$ CFU/mL & $\mathbf{8} \log$ CFU/mL \\
\hline S. aureus subsp. aureus & $12.5 / 12.5$ & $25.0 / 50.0$ & $200.0 / 400.0$ \\
\hline B. cereus & $12.5 / 50.0$ & $12.5 / 50.0$ & $25.0 / 50.0$ \\
\hline L. innocua & $12.5 / 25.0$ & $12.5 / 50.0$ & $25.0 / 100.0$ \\
\hline E. coli & $12.5 / 25.0$ & $25.0 / 25.0$ & $200.0 / 400.0$ \\
\hline S. enterica subsp. enterica & $12.5 / 25.0$ & $25.0 / 50.0$ & $200.0 / 200.0$ \\
\hline
\end{tabular}

Both MIC and MBC values correlate with the initial biomass of the pathogen, where, with an increase in bacterial density, higher concentrations of HBV were needed for bacteriostatic and bactericidal effects. At lower and medium initial biomass levels, similar HBV concentrations ( $3 \log$ CFU $/ \mathrm{mL}: 12.5 \mu \mathrm{g} / \mathrm{mL} ; 6 \log$ CFU $/ \mathrm{mL}: 12.5-25.0 \mu \mathrm{g} / \mathrm{mL}$ ) suppressed the growth or completely inhibited (3 log CFU/mL: $12.5-50.0 \mu \mathrm{g} / \mathrm{mL} ; 6 \log \mathrm{CFU} / \mathrm{mL}-$ $25.0-50.0 \mu \mathrm{g} / \mathrm{mL})$ all tested pathogens. When biomass was extremely high $(8 \log \mathrm{CFU} / \mathrm{mL})$, high HBV concentrations were needed to inhibit $(25.0-200.0 \mu \mathrm{g} / \mathrm{mL})$ or to completely kill $(50.0-400.0 \mu \mathrm{g} / \mathrm{mL})$ all tested bacterial strains. 
In the studies of Oren and Shai [41], Han et al. [32], and Ebbensgaard et al. [42], lower or higher MIC values were reported compared to the results demonstrated in this study. However, in the aforementioned papers, the antibacterial activity of pure mellitin was predominantly tested, which makes it difficult to compare it with our results. For example, Oren and Shai [39], showed that mellitin inhibited the growth of E. coli at $5 \mu \mathrm{M}$, and different Bacillus species at 0.3-0.4 $\mu \mathrm{M}$, while Ebbensgaard et al. [42] showed that mellitin inhibited E. coli at $16 \mu \mathrm{g} / \mathrm{mL}$, and both S. aureus and L. monocytogenes at $2-4 \mu \mathrm{g} / \mathrm{mL}$. On the contrary, Ebbensgaard et al. [42] determined a higher MIC of mellitin for Salmonella enterica $(32-64 \mu \mathrm{g} / \mathrm{mL})$.

Contrary to our study, Hegazi et al. [11] reported much higher MIC values of whole honey bee venom varying from 1600 to $3600 \mu \mathrm{g} / \mathrm{mL}$ for $S$. aureus, and from 1800 to $3800 \mu \mathrm{g} / \mathrm{mL}$ for E. coli, while Han et al. [22], on the other hand, detected much lower MIC values of whole honey bee venom, ranging from 0.085 to $0.11 \mu \mathrm{g} / \mathrm{mL}$ for methicillinresistant S. aureus. Such differences can be attributed to the extraction method and additional venom purification, resulting in different HBV purity and mellitin content values. For example, while Hegazi et al. [11] obtained honey bee venom either by homogenization of the bee venom sac in ethanol or whole bees in saline solution, we collected the HBV by scraping the dried HBV from a glass plate covered with plastic foil, following the electro-stimulation method, which may have directly increased the HBV purity in our study. Unlike our study, Han et al. [22] further purified bee venom before the antimicrobial activity testing, which may have led to the concentration of bioactive compounds, such as mellitin, in whole honey bee venom.

Similarly to our study, Han et al. [32] investigated the antimicrobial activity of whole HBV where MIC for E. coli was $0.25 \mu \mathrm{g} / \mathrm{mL}$ and for S. aureus $0.06 \mu \mathrm{g} / \mathrm{mL}$. On the contrary, Al-Ani et al. [34] detected a much higher MIC of whole HBV for S. aureus $(10-60 \mu \mathrm{g} / \mathrm{mL})$ and E. coli $(60-200 \mu \mathrm{g} / \mathrm{mL})$. Such differences could be explained by different bacterial species and strains, and different initial biomass used. Although our results are in line with previous studies as the lowest MIC value in our study was $12.5 \mu \mathrm{g} / \mathrm{mL}$, to increase the resolution, especially at the lower range, $\mathrm{HBV}$ concentrations $<12.5 \mu \mathrm{g} / \mathrm{mL}$ should be tested.

Furthermore, in the case when bacterial growth was detected in our study only in the control wells after $24 \mathrm{~h}$, the incubation was prolonged, and MIC and MBC values were determined after $48 \mathrm{~h}$. The growth of L. innocua, S. enterica subsp. enterica and E. coli treated with HBV could only be detected after $48 \mathrm{~h}$; thus, the true HBV killing potential could be determined only after prolonged incubation. L. innocua, S. enterica subsp. enterica and E. coli are known for forming biofilms [43,44], which provide certain survival advantages. In addition to the development of complex nutrient and oxygen gradients, biofilms often contain extracellular enzymes that are important for microbial cell nutrition, thus allowing the transfer of molecules involved in cellular communication. In addition, they protect microbial cells from adverse physical (e.g., dehydration) and chemical factors, such as substances with antimicrobial activity [45].

Generally, the MBC values for all tested pathogens were either the same or double when compared to MIC values, except for B. cereus, most likely due to its ability to sporulate [46] and survive adverse conditions.

\subsection{Comparison of Antibacterial Activity of $\mathrm{HBV}$ and Conventional Antibiotics}

Antibacterial activity of HBV (100-400 $\mu \mathrm{g}$ ) and conventional antibiotics (tetracycline (TE $30 \mu \mathrm{g}$ ) and erythromycin (E $15 \mu \mathrm{g}$ ) for Gram-positive bacteria, and ciprofloxacin (CIP $5 \mu \mathrm{g}$ ) and ampicillin-sulbactam (SAM $10 \mu \mathrm{g}+10 \mu \mathrm{g}$ ) for Gram-negative bacteria) was determined by the disc diffusion method. The sensitivity of all pathogens to HBV was achieved at $100 \mu \mathrm{g}$ for Gram-negative and $300 \mu \mathrm{g}$ for Gram-positive bacteria. Increased concentrations of $\mathrm{HBV}$, up to $400 \mu \mathrm{g}$, were applied in order to achieve saturation. The results are summarized in Table 2. 
Table 2. In vitro antibacterial activity of HBV and conventional antibiotics as shown by disc diffusion method. Each result is presented as a mean inhibition zone in $\mathrm{mm} \pm$ standard deviation $(n=3)$. Statistical differences were determined by analysis of variance (ANOVA) and the post-hoc Tukey HSD test.

\begin{tabular}{|c|c|c|c|c|c|c|c|c|}
\hline $\begin{array}{c}\text { Bacterial } \\
\text { Strains }\end{array}$ & HBV $(100 \mu g)$ & HBV $(200 \mu g)$ & HBV $(300 \mu \mathrm{g})$ & HBV $(400 \mu \mathrm{g})$ & TE $(30 \mu g)$ & E $(15 \mu g)$ & CIP $(5 \mu \mathrm{g})$ & SAM $(20 \mu g)$ \\
\hline $\begin{array}{c}\text { S. aureus } \\
\text { subsp. aureus }\end{array}$ & $8.5 \pm 0.7^{\text {afgh }}$ & $9.6 \pm 0.1^{b}$ & $9.6 \pm 0.1 \mathrm{bg}$ & $9.6 \pm 0.1^{\mathrm{bg}}$ & $33.0 \pm 0.0$ & $28.8 \pm 0.4$ & n.d. & n.d. \\
\hline B. cereus & $6.0 \pm 0.0^{\mathrm{d}}$ & $7.0 \pm 0.0^{\mathrm{e}}$ & $8.0 \pm 0.0$ af & $8.8 \pm 0.4^{\text {afgh }}$ & $31.5 \pm 2.1$ & $16.8 \pm 0.4$ & n.d. & n.d. \\
\hline L. innocua & $0.0 \pm 0.0^{c}$ & $0.0 \pm 0.0^{c}$ & $8.3 \pm 0.4^{\text {afgh }}$ & $8.5 \pm 0.1^{\text {afgh }}$ & $41.5 \pm 2.1$ & $38.5 \pm 2.1$ & n.d. & n.d. \\
\hline E. coli & $6.5 \pm 0.0 \mathrm{de}$ & $8.0 \pm 0.0^{f}$ & $9.0 \pm 0.0^{g}$ & $9.0 \pm 0.0^{\text {abgh }}$ & n.d. & n.d. & $42.5 \pm 0.7$ & $26.0 \pm 0.0$ \\
\hline $\begin{array}{c}\text { S. enterica } \\
\text { subsp. enterica }\end{array}$ & $6.3 \pm 0.4^{\text {de }}$ & $6.0 \pm 0.0^{\mathrm{d}}$ & $8.5 \pm 0.0^{\mathrm{h}}$ & $9.0 \pm 0.0^{\mathrm{bh}}$ & n.d. & n.d. & $45.5 \pm 0.3$ & $27.8 \pm 1.8$ \\
\hline
\end{tabular}

HBV—honey bee venom; TE—-tetracycline; E—erythromycin; CIP_ciprofloxacin; SAM-ampicillin-sulbactam; n.d. = not determined; a-h mark significant differences $(p<0.01)$.

All pathogens were sensitive to conventional antibiotics and their sensitivity to HBV increased with the HBV concentration. Only minor differences were observed between 300 and $400 \mu \mathrm{g}$ of $\mathrm{HBV}$, indicating that saturation in HBV concentration was achieved. At HBV concentrations of $300 \mu \mathrm{g}, 29.1 \pm 0.4 \%$ TE efficiency and $33.4 \pm 0.1 \%$ E efficiency were reached when applied to $S$. aureus; in addition, $25.5 \pm 1.7 \%$ TE efficiency and $47.8 \pm 1.0 \%$ E efficiency towards B. cereus, and $19.9 \pm 0.2 \%$ TE efficiency and $21.4 \pm 0.3 \%$ E efficiency towards L. innocua, were achieved.

At HBV concentrations of $100 \mu \mathrm{g}$, E. coli was more sensitive to HBV than S. enterica. More specifically, at HBV concentrations of $100 \mu \mathrm{g}, 15.3 \pm 0.3 \% \mathrm{CIP}$ and $25.0 \pm 0.0 \%$ SAM efficiency when applied to $E$. coli, and $13.8 \pm 1.8 \% \mathrm{CIP}$ and $22.6 \pm 2.7 \%$ SAM towards $S$. enterica, was reached.

The disc diffusion method showed that $S$. aureus was the most sensitive to the HBV. In general, Gram-positive pathogens were found to be more sensitive to HBV than Gramnegative, $[11,47,48]$. Due to the differences in the cell wall structure, mellitin, the main component of bee venom, can more easily penetrate the peptidoglycan layer of the Grampositive bacteria $[32,35,49]$. The detected differences in HBV antibacterial activity may arise due to differences in methodology, the effect of inoculum, and the stability of antimicrobial compounds [50].

Furthermore, the antimicrobial activity of $\mathrm{HBV}$ at the highest tested concentration of $400 \mu \mathrm{g}$ showed a considerable efficiency of conventional antibiotics. For example, HBV showed up to $27.8 \% \mathrm{TE}$ and $52.2 \%$ E efficiency when applied to Gram-positive bacteria, and up to $21.2 \%$ CIP and 34.6\% SAM in Gram-negative bacteria. Some studies have revealed that the antimicrobial activity of HBV increases when applied in combination with conventional antibiotics [22,34], where HBV interacts with cell membranes and forms ion channels, thus altering the permeability of the cytoplasmic membrane. In this way, HBV can simultaneously allow other substances, such as antibiotics, to enter the cell and cause cell lysis [51].

\section{Materials and Methods}

\subsection{Honey Bee Venom Collection}

Honey bee venom was obtained directly from the primary producer with an apiary situated in Bjelovar-Bilogora County (Croatia) during 2018. HBV was collected from 100 Carniolan honey bee (Apis mellifera carnica Pollman, 1879) colonies (pooled sample) by an electro-stimulation method. An internal bee venom collector, placed at the top of the 10-frame Langstroth hives under a dome, was powered by a 12-volt battery. Honey bees were stimulated with electric impulses $(12 \mathrm{~V})$ for $10 \mathrm{~s}$ followed by $10 \mathrm{~s}$ pauses. During the electro-stimulation, the bee workers stung the glass plates through a plastic foil. Venom was left to dry at $27^{\circ} \mathrm{C}$ and a relative humidity of $50 \%$ for $35 \mathrm{~min}$ and collected by scraping the dried HBV (powder) from the glass slide of the venom collector using a sharp scraper. Dried HBV was stored in the dark and dry place at $4{ }^{\circ} \mathrm{C}$ prior to further analyses. 


\subsection{Chemical Characterization of Honey Bee Venom}

Detailed chemical profiling of collected A. mellifera venom sample was carried out to determine the content of targeted bioactive compounds and to ensure the purity of the sample prior to further microbiological assay.

\subsubsection{Determination of Melittin in Honey Bee Venom Using High-Performance Liquid Chromatography (HPLC)}

A modified version of the reversed-phase chromatography method of Rybak-Chmielewska and Szczęsna [52] was applied for the determination of the melittin content in the honey bee venom using an HPLC UV detector (Agilent 1200, Palo Alto, CA, USA). Chromatographic separation was achieved using a C18 HPLC column, linear gradient elution (B 5-80\% $40 \mathrm{~min}$ ) using two different mobile phases: mobile phase $\mathrm{A}$ was $0.1 \%$ trifluoroacetic acid in water, and mobile phase B was $0.1 \%$ trifluoroacetic acid in $80 \%$ acetonitrile (flow rate: $2.0 \mathrm{~mL} / \mathrm{min}$; column temperature: $25^{\circ} \mathrm{C}$ ). The chromatographic detection of melittin was achieved with a UV detector at $220 \mathrm{~nm}$. The amount of melittin in the sample was determined by the external standard method using the calibration curve $(k>0.999)$, and the result was expressed in percentage $(\%)$. The standards were supplied by Sigma-Aldrich. The analysis was performed in triplicate and the results are expressed as mean values with standard deviation.

\subsubsection{Determination of Total Proteins in Honey Bee Venom}

Protein (nitrogen) content was determined according to the standard ISO 1871:2009 [53] (Kjeldahl method using Kjeltec TM 2100, FOSS (Haganäs, Sweden)). A quantity of $0.5000 \mathrm{~g}$ of venom was weighed in Kjeldahl digestion tubes with $5 \mathrm{~g}$ of Kjeldahl catalyst tablets. In addition, $12 \mathrm{~mL}$ of concentrated sulfuric acid $(97 \%)$ was added to the tubes. The suspension was carefully mixed and left overnight. Digestion tubes were transferred to the digestion unit for mineralization under vacuum. The temperature was gradually increased and the process was finished when the solution became clear and light green with no visible particles. Tubes were transferred and cooled to room temperature. Afterward, $80 \mathrm{~mL}$ of distilled water was added and tubes with samples were put into the Kjeltec system. Ammonia uptake after distillation was performed in an Erlenmeyer flask containing $25 \mathrm{~mL}$ of $4 \%$ boric acid with an indicator. The alkaline solution was dosed in five $10 \mathrm{~mL}$ portions and the distillation took place automatically for $4 \mathrm{~min}$. Due to the presence of ammonia, the distillate turns green over time. The burette was loaded with $0.1 \mathrm{~mol} \mathrm{dm}^{-3} \mathrm{HCl}$ (volumetric standard) and used for titration of the flask content after distillation in a Kjeltec system. At the endpoint of the titration, the color of the solution became pale pink. The volume of hydrochloric acid for the titration of the sample was recorded. The analysis was performed in triplicate and the results were expressed as mean values with standard deviation. Nitrogen content (\%) was calculated according to the Equation (1):

$$
\% N=\frac{\left[(a-b) \times c_{\text {acid }} \times f_{\text {acid }} \times 1.4007\right]}{m_{\text {sample }}}
$$

where $a$ is the volume of $\mathrm{HCl}$ spent for titration of the sample $(\mathrm{mL}), b$ is the volume of $\mathrm{HCl}$ spent for titration of blank (mL), $c$ is the concentration $(\mathrm{mol} / \mathrm{L}), f$ is the acid factor, and $m$ is the sample weight $(\mathrm{g})$.

\subsubsection{Chemical Fingerprinting by FTIR-ATR Spectroscopy}

In addition to the analytical methods applied for quantifying major peptide/protein fractions, the sample was analyzed by infrared (IR) spectroscopy in order to provide an insight into the total chemical composition and ensure the purity of investigated HBV sample.

Dried HBV sample (powder) was analyzed by Fourier transform infrared spectroscopy (FTIR) coupled with the Attenuated Total Reflectance (ATR) recording technique to provide an insight into its total chemical composition. Infrared (IR) spectra of the bee venom sample were acquired using the Cary 660 Fourier FTIR spectrometer (Agilent Technologies, Palo Alto, CA, USA) and the Golden Gate single-reflection diamond ATR accessory (Specac). 
The sample was analyzed as obtained (it was only pulverized into a finer powder with a porcelain mortar). Approximately $50 \mathrm{mg}$ of bee venom powder was used to acquire the spectra of a thin uniform layer of the sample. This was achieved by pressuring the bee venom powder on a diamond ATR plate using a self-leveling sapphire anvil. Absorption spectra were recorded in a mid-infrared region $\left(4000-400 \mathrm{~cm}^{-1}\right)$ using a nominal resolution of $4 \mathrm{~cm}^{-1}$ (at $23 \pm 2{ }^{\circ} \mathrm{C}$ ). Two replicate spectra of the sample (32 scans per spectrum) were recorded using different aliquots. Raw spectral data were stored and pre-analyzed using the Agilent Resolutions Pro version 5.3.0 software package (Agilent Technologies, Palo Alto, CA, USA), and further spectral data analysis and processing were carried out using Origin version 8.1 (Origin Lab Corporation). An assignation of molecular vibrations observed in the bee venom spectrum was performed using electronic spectral libraries (NIST, IMB Jena Image Library of Biological Macromolecules, Agilent Technologies, Palo Alto, CA, USA) in combination with venom-relating spectral data from the available scientific literature.

To ensure the purity of the investigated bee venom sample (absence of hive-originating impurities/particles, such as beeswax, propolis, bee pollen, or nectar), the spectra of analyzed bee venom powder were compared with a spectrum of genuine bee venom sample collected directly from a 24-day old worker bee (forager) in a liquid form using a $10 \mu \mathrm{L}$ microcapillary tube sting stimulation (internal spectral collection of authentic bee venom stored at Laboratory for bee products analysis and bee biology, University of Zagreb Faculty of Agriculture).

\subsection{Evaluation of Bee Venoms' Antibacterial Activity \\ 3.3.1. Bacterial Strains}

The bacterial strains used in this study were S. aureus subsp. aureus (DSM 20231), B. cereus (DSM 6791) and S. enterica subsp. enterica (DSM 14221) from the German Collection of Microorganisms and Cell Cultures, and L. innocua (ATCC 3309) and E. coli (ATCC 25922) from American Type Culture Collection. All isolates were stored as glycerol (25\%) culture at $-20{ }^{\circ} \mathrm{C}$ in the Department of Microbiology, University of Zagreb Faculty of Agriculture.

\subsubsection{Determination of Minimum Inhibitory (MIC) and Bactericidal (MBC) Concentrations}

The minimum inhibitory (MIC) and minimum bactericidal (MBC) concentrations of HBV were determined by broth microdilution according to the Clinical and Laboratory Standards Institute reference method M27-A3 [54] in 96-well microtiter plates (SigmaAldrich, Taufkirchen, Germany). MIC and MBC were determined for three different cell densities $(3,6$, and $8 \log \mathrm{CFU} / \mathrm{mL})$ for all tested pathogens. Several colonies of pure culture were inoculated in $10 \mathrm{~mL}$ of sterile saline solution $(0.85 \%)$ under sterile conditions until a cell concentration corresponding to the $0.5 \mathrm{McFarland}$ standard $\left(1.5 \times 10^{8} \mathrm{CFU} / \mathrm{mL}\right)$ was achieved. Cell suspensions were then diluted in sterile saline solution $(0.85 \%)$ to obtain target biomass.

HBV was dissolved in distilled water and then filtered through a membrane filter (0.22 $\mu \mathrm{m}$ pore size, Millipore, Billerica, MA, USA) to obtain a working solution of HBV $(1000 \mu \mathrm{g} / \mathrm{mL})$. HBV was serially diluted two-fold in Mueller-Hinton broth in microtiter plates, to test the HBV concentration range $12.5-800 \mu \mathrm{g} / \mathrm{mL}$. All tested pathogens $(3,6$, and $8 \log \mathrm{CFU} / \mathrm{mL}$ ) were incubated with two-fold serial dilutions of $\mathrm{HBV}$, at $37^{\circ} \mathrm{C}$ for 24 or $48 \mathrm{~h}$ under constant agitation ( $90 \mathrm{rpm} / \mathrm{min}$; Orbital Shaker-Incubator ES-20, Biosan, Latvia). The experiment was performed in triplicates. The bacterial growth was measured by the spectrophotometric assay as turbidity at $660 \mathrm{~nm}$ wavelength (EL80, BioTek Instruments, VT, USA). The bacterial growth inhibition was calculated according to Equation (2):

$$
\text { Growth inhibition }[\%]=100 \times\left[1-\left(\frac{\mathrm{A}_{\mathrm{t}}-\mathrm{A}_{0}}{\mathrm{~A}_{\mathrm{ct}}-\mathrm{A}_{\mathrm{c} 0}}\right)\right]
$$

where $A_{t}$ is the absorbance of $\mathrm{MH}+\mathrm{HBV}+$ bacterial suspension measured after 24 or $48 \mathrm{~h}$, $\mathrm{A}_{0}$ the absorbance of $\mathrm{MH}+\mathrm{HBV}+$ bacterial suspension measured at the beginning of the experiment $(0 \mathrm{~h}), \mathrm{A}_{\mathrm{ct}}$ the absorbance of $\mathrm{MH}+$ bacterial suspension measured after 24 or 
$48 \mathrm{~h}$, and $\mathrm{A}_{\mathrm{c} 0}$ the absorbance of $\mathrm{MH}+$ bacterial suspension measured at the beginning of the experiment $(0 \mathrm{~h})$.

\subsubsection{Antibacterial Assay of Bee Venom and Conventional Antibiotics}

The antibacterial effects of HBV and conventional antibiotics were tested by using disc diffusion assays $[55,56]$. Pure cultures were prepared by culturing the test strains in $1.5 \mathrm{~mL}$ of brain heart infusion broth (BHI broth, Biolife, Italy). After the incubation at $30{ }^{\circ} \mathrm{C}$ for $24 \mathrm{~h}$, the test strains were streaked on $\mathrm{BHI}$ agar plates and incubated for an additional $24 \mathrm{~h}$, in order to obtain a pure culture. Several colonies were taken with a sterile loop and inoculated in $10 \mathrm{~mL}$ of sterile saline solution $(0.85 \%)$ at a cell concentration corresponding to $0.5 \mathrm{McF}$ arland standard $\left(1.5 \times 10^{8} \mathrm{CFU} / \mathrm{mL}\right)$. A sterile cotton swab was used for spreading diluted cell suspension on Mueller-Hinton (MH, Biolife, Italy) agar plates. Sterile blank paper discs (7-mm diameter, Biorad, France) were then placed on the MH agar's surface, and HBV (100 $\mu \mathrm{g}, 200 \mu \mathrm{g}, 300 \mu \mathrm{g}$, and $400 \mu \mathrm{g})$ was added to each disc. Three replicates were made for each treatment. The results were presented as a mean inhibition zone, including the diameter of the disc, in $\mathrm{mm}$.

Antibiogram disks including tetracycline (TE; $30 \mu \mathrm{g})$ and erythromycin $(\mathrm{E} ; 15 \mu \mathrm{g})$ for Gram-positive isolates, and ciprofloxacin (CIP; $5 \mu \mathrm{g}$ ) and ampicillin-sulbactam (SAM; $10 \mu \mathrm{g}+10 \mu \mathrm{g}$ ) for Gram-negative isolates, were added. The plates were incubated at $37^{\circ} \mathrm{C}$ for $24 \mathrm{~h}$, and the zones of inhibition were measured. The results were calculated as mean inhibition zone in $\mathrm{mm}$, and as a percentage (\%) of antimicrobial activity compared to the antimicrobial activity of tetracycline and erythromycin for Gram-positive isolates, and ciprofloxacin and ampicillin-sulbactam for Gram-negative isolates.

\subsection{Statistical Analysis}

All data were expressed as mean values \pm standard deviation of the mean (SD). Statistical differences between groups were determined using Analysis of Variance (ANOVA) followed by the post-hoc Tukey HSD test. Differences with $p<0.01$ were considered significant. All statistical analyses were performed in R environment version 3.0.2 [57].

\section{Conclusions}

The chemical composition, purity, and antibacterial activity of honey bee venom (HBV) obtained directly from the primary producer were investigated in this study. The analyzed HBV showed above-average high-quality properties with melittin and total protein contents of $70.10 \pm 7.01 \%$, and $84.44 \pm 3.12 \mathrm{~g} / 100 \mathrm{~g}$, respectively. The results of the spectral analysis revealed a characteristic FTIR-ATR spectrum of HBV powder distinguished by a unique pattern of absorption bands primarily arising from molecular vibrations related to the major fractions of HBV-peptides and proteins. Besides high melittin and protein content, the broad spectrum of antibacterial activity of the investigated HBV against all tested potentially pathogenic Gram-positive and Gramnegative bacteria (Staphylococcus aureus, Listeria innocua, Bacillus cereus, Escherichia coli and Salmonella enterica) was observed, irrespective of the bacterial biomass applied (3, 6 or $8 \log$ CFU/mL). The MIC values ranged between 12.5 and $200 \mu \mathrm{g} / \mathrm{mL}(3 \log$ CFU $/ \mathrm{mL}$ : $12.5 \mu \mathrm{g} / \mathrm{mL} ; 6 \log$ CFU $/ \mathrm{mL}: 12.5-25.0 \mu \mathrm{g} / \mathrm{mL} ; 8 \log$ CFU $/ \mathrm{mL}: 25-200 \mu \mathrm{g} / \mathrm{mL}$ ), and MBC values ranged between 12.5 and $400 \mu \mathrm{g} / \mathrm{mL}(3 \log \mathrm{CFU} / \mathrm{mL}: 12.5-50.0 \mu \mathrm{g} / \mathrm{mL} ; 6 \log$ CFU $/ \mathrm{mL}: 25.0-50.0 \mu \mathrm{g} / \mathrm{mL} ; 8 \log$ CFU $/ \mathrm{mL}: 50.0-400 \mu \mathrm{g} / \mathrm{mL})$. When compared to conventional antibiotics, HBV $(400 \mu \mathrm{g})$ showed up to $27.8 \%$ efficiency of tetracycline ( $30 \mu \mathrm{g})$, $52.2 \%$ erythromycin $(15 \mu \mathrm{g}), 21.2 \%$ ciprofloxacin $(5 \mu \mathrm{g})$, and $34.6 \%$ of ampicillin-sulbactam $(20 \mu \mathrm{g})$. The results presented in this study revealed above-average high-quality properties of investigated honey bee venom, and indicate that $\mathrm{HBV}$ is a good source of alternative antimicrobial compounds. 
Author Contributions: Conceptualization, I.T., L.S. and M.M.F.; Data curation, I.T., L.S. and D.G.; Formal analysis, I.T., L.S., D.G. and M.L.; Investigation, I.T., L.S., D.G. and M.L.; Methodology, I.T., L.S., D.G., M.L. and S.J.; Resources, M.V. and M.M.F.; Supervision, M.M.F.; Visualization, I.T. and L.S.; Writing-original draft, I.T., L.S. and D.G.; Writing—review and editing, S.J., M.V. and M.M.F. All authors have read and agreed to the published version of the manuscript.

Funding: This work was supported by the Paying Agency for Agriculture, Fisheries and Rural Development of the Republic of Croatia as part of the project "Detailed characterization and antimicrobial activity of bee products: inhibition of growth of antibiotic-resistant pathogenic bacteria".

Acknowledgments: The authors would like to thank to Tvrtko Matijević, mag. ing. agr. for the HBV sampling support.

Conflicts of Interest: The authors declare no conflict of interest.

Sample Availability: Samples of the compounds are available from the authors.

\section{References}

1. Ventola, C.L. The antibiotic resistance crisis: Part 1: Causes and threats. Pharm. Ther. 2015, 40, $277-283$.

2. Hancock, R.E.W.; Sahl, H.G. Antimicrobial and host-defense peptides as new anti-infective therapeutic strategies. Nat. Biotechnol. 2006, 24, 1551-1557. [CrossRef] [PubMed]

3. Ghosh, C.; Haldar, J. Membrane-active small molecules: Designs inspired by antimicrobial peptides. Chem. Med. Chem. 2015, 10, 1606-1624. [CrossRef] [PubMed]

4. Jenssen, H.; Hamill, P.; Hancock, R.E.W. Peptide antimicrobial agents. Clin. Microbiol. Rev. 2006, 19, 491-511. [CrossRef]

5. Perumal Samy, R.; Stiles, B.G.; Franco, O.L.; Sethi, G.; Lim, L.H.K. Animal venoms as antimicrobial agents. Biochem. Pharmacol. 2017, 134, 127-138. [CrossRef]

6. Yacoub, T.; Rima, M.; Karam, M.; Sabatier, J.M.; Fajloun, Z. Antimicrobials from venomous animals: An overview. Molecules 2020, 25, 2402. [CrossRef]

7. De Castro Figueiredo Bordon, K.; Cologna, C.T.; Fornari-Baldo, E.C.; Pinheiro-Júnior, E.L.; Cerni, F.A.; Amorim, F.G.; Anjolette, F.A.P.; Cordeiro, F.A.; Wiezel, G.A.; Cardoso, I.A.; et al. From animal poisons and venoms to medicines: Achievements, challenges and perspectives in drug discovery. Front. Pharmacol. 2020, 11, 1132. [CrossRef]

8. Carpena, M.; Nuñez-Estevez, B.; Soria-Lopez, A.; Simal-Gandara, J. Bee venom: An updating review of its bioactive molecules and its health applications. Nutrients 2020, 12, 3360. [CrossRef]

9. Liu, X.; Chen, D.; Xie, L.; Zhang, R. Effect of honey bee venom on proliferation of K1735M2 mouse melanoma cells in-vitro and growth of murine B16 melanomas in-vivo. J. Pharm. Pharmacol. 2002, 54, 1083-1089. [CrossRef]

10. Oršolić, N. Bee venom in cancer therapy. Cancer Metastasis Rev. 2012, 31, 173-194. [CrossRef]

11. Hegazi, A.; Abdou, A.M.; El-Moez, S.I.; Allah, F.A. Evaluation of the antibacterial activity of bee venom from different sources. World Appl. Sci. J. 2014, 30, 266-270.

12. Ko, S.J.; Park, E.; Asandei, A.; Choi, J.Y.; Lee, S.C.; Seo, C.H.; Luchian, T.; Park, Y. Bee venom-derived antimicrobial peptide melectin has broad-spectrum potency, cell selectivity, and salt-resistant properties. Sci. Rep. 2020, 10, 10145. [CrossRef]

13. Park, J.H.; Kim, K.H.; Kim, S.J.; Lee, W.R.; Lee, K.G.; Park, K.K. Bee venom protects hepatocytes from tumor necrosis factor- $\alpha$ and actinomycin D. Arch. Pharm. Res. 2010, 33, 215-223. [CrossRef]

14. Liu, C.C.; Yang, H.; Zhang, L.L.; Zhang, Q.; Chen, B.; Wang, Y. Biotoxins for cancer therapy. Asian Pac. J. Cancer Prev. 2014, 15, 4753-4758. [CrossRef]

15. Bogdanov, S. Bee venom: Production, composition, quality. In The Bee Venom Book; e-book Bee Product Science: Muehlethurnen, Switzerland, 2016; pp. 1-8.

16. Pascoal, A.; Estevinho, M.M.; Choupina, A.B.; Sousa-Pimenta, M.; Estevinho, L.M. An overview of the bioactive compounds, therapeutic properties and toxic effects of apitoxin. Food Chem. Toxicol. 2019, 134, 110864. [CrossRef]

17. Abd El-Wahed, A.A.; Khalifa, S.A.M.; Sheikh, B.Y.; Farag, M.A.; Saeed, A.; Larik, F.A.; Koca-Caliskan, U.; AlAjmi, M.F.; Hassan, M.; Wahabi, H.A.; et al. Bee venom composition: From chemistry to biological activity. Stud. Nat. Prod. Chem. 2018, 60, 459-484.

18. Wehbe, R.; Frangieh, J.; Rima, M.; El Obeid, D.; Sabatier, J.M.; Fajloun, Z. Bee venom: Overview of main compounds and bioactivities for therapeutic interests. Molecules 2019, 24, 2997. [CrossRef] [PubMed]

19. Dong, J.; Ying, B.; Huang, S.; Ma, S.; Long, P.; Tu, X.; Yang, W.; Wu, Z.; Chen, W.; Miao, X. High-performance liquid chromatography combined with intrinsic fluorescence detection to analyse melittin in individual honeybee (Apis mellifera) venom sac. J. Chromatogr. B 2015, 1002, 139-143. [CrossRef]

20. Fennell, J.F.; Shipman, W.H.; Cole, L.J. Antibacterial Action of a Bee Venom Fraction (Melittin) against a Penicillin-Resistant Staphylococcus and Other Microorganisms; Research and Development Technical Report; United States Naval Radiological Defense Laboratory: San Francisco, CA, USA, 1967; pp. 1-25.

21. Raghuraman, H.; Chattopadhyay, A. Melittin: A membrane-active peptide with diverse functions. Biosci. Rep. 2007, 27, 189-223. [CrossRef] 
22. Han, S.M.; Kim, J.M.; Hong, I.P.; Woo, S.O.; Kim, S.G.; Jang, H.R.; Pak, S.C. Antibacterial activity and antibiotic-enhancing effects of honeybee venom against methicillin-resistant staphylococcus aureus. Molecules 2016, 21, 79. [CrossRef] [PubMed]

23. Mouton, J.W.; Vinks, A.A. Relationship between minimum inhibitory concentration and stationary concentration revisited. Clin. Pharmacokinet. 2005, 44, 767-768. [CrossRef] [PubMed]

24. Udekwu, K.I.; Parrish, N.; Ankomah, P.; Baquero, F.; Levin, B.R. Functional relationship between bacterial cell density and the efficacy of antibiotics. J. Antimicrob. Chemother. 2009, 63, 745-757. [CrossRef]

25. Clinical \& Laboratory Standards Institute. Performance Standards for Antimicrobial Susceptibility Testing; Twenty-Fifth Informational Supplement; CLSI Document M100-S25; CLSI: Wayne, PA, USA, 2015.

26. EUCAST. Disk Diffusion Method for Antimicrobial Susceptibility Testing, v 9.0. EUCAST. 2021. Available online: https: / / eucast.org (accessed on 12 May 2021).

27. Chen, J.; Guan, S.M.; Sun, W.; Fu, H. Melittin, the major pain-producing substance of bee venom. Neurosci. Bull. 2016, 32, 265-272. [CrossRef] [PubMed]

28. Pucca, M.B.; Cerni, F.A.; Oliveira, I.S.; Jenkins, T.P.; Argemí, L.; Sørensen, C.V.; Ahmadi, S.; Barbosa, J.E.; Laustsen, A.H. Bee updated: Current knowledge on bee venom and bee envenoming therapy. Front. Immunol. 2019, 10, 2090. [CrossRef] [PubMed]

29. Abrantes, A.F.; da Rocha, T.C.; de Lima, A.B.S.; Cavalcanti, M.T. Honeybee venom: Influence of collection on quality and cytotoxicity. Ciência Rural 2017, 47, e20160486. [CrossRef]

30. Costa, H.; Boni-Mitake, M.; Souza, C.F.; Rogero, J.R. Effects of gamma radiation on bee venom: Preliminary studies. VII Gen. Congr. Nucl. Energy 1999, 1-4.

31. Darwish, D.A.; Masoud, H.M.M.; Abdel-Monsef, M.M.; Helmy, M.S.; Zidan, H.A.; Ibrahim, M.A. Phospholipase A2 enzyme from the venom of Egyptian honey bee Apis mellifera lamarckii with anti-platelet aggregation and anti-coagulation activities. J. Genet. Eng. Biotechnol. 2021, 19, 1-8. [CrossRef]

32. Han, S.; Yeo, J.; Baek, H.; Lin, S.M.; Meyer, S.; Molan, P. Postantibiotic effect of purified melittin from honeybee (Apis mellifera) venom against Escherichia coli and Staphylococcus aureus. J. Asian Nat. Prod. Res. 2009, 11, 796-804. [CrossRef]

33. Park, D.; Jung, J.W.; Lee, M.O.; Lee, S.Y.; Kim, B.; Jin, H.J.; Kim, J.; Ahn, Y.J.; Lee, K.W.; Song, Y.S.; et al. Functional characterization of naturally occurring melittin peptide isoforms in two honey bee species, Apis mellifera and Apis cerana. Peptides 2014, 53, 185-193. [CrossRef]

34. Al-Ani, I.; Zimmermann, S.; Reichling, J.; Wink, M. Pharmacological synergism of bee venom and melittin with antibiotics and plant secondary metabolites against multi-drug resistant microbial pathogens. Phytomedicine 2015, 22, 245-255. [CrossRef]

35. Picoli, T.; Peter, C.M.; Zani, J.L.; Waller, S.B.; Lopes, M.G.; Boesche, K.N.; Vargas, G.D.; de Oliveira Hübner, S.; Fischer, G. Melittin and its potential in the destruction and inhibition of the biofilm formation by Staphylococcus aureus, Escherichia coli and Pseudomonas aeruginosa isolated from bovine milk. Microb. Pathog. 2017, 112, 57-62. [CrossRef] [PubMed]

36. De Graaf, D.C.; Brochetto Braga, M.R.; de Abreu, R.M.M.; Blank, S.; Bridts, C.H.; De Clerck, L.S.; Devreese, B.; Ebo, D.G.; Ferris, T.J.; Hagendorens, M.M.; et al. Standard methods for Apis mellifera venom research. J. Apic. Res. 2020, 1-31. [CrossRef]

37. Banks, B.E.C.; Shipolini, R.A. Chemistry and Pharmacology of Honey-bee Venom. In Venoms of the Hymenoptera: Biochemical, Pharmacological and Behavioural Aspects; Piek, A., Ed.; Academic Press: Orlando, FL, USA, 1986; pp. 329-416.

38. Socrates, G. Infrared and Raman Characteristic Group Frequencies: Tables and Charts; John Wiley \& Sons: New York, NY, USA, 2004.

39. Kong, J.; Yu, S. Fourier transform infrared spectroscopic analysis of protein secondary structures. Acta Biochim. Biophys. Sin. (Shanghai) 2007, 39, 549-559. [CrossRef] [PubMed]

40. Park, M.H.; Jun, H.S.; Jeon, J.W.; Park, J.K.; Lee, B.J.; Suh, G.H.; Park, J.S.; Cho, C.W. Preparation and characterization of bee venom-loaded PLGA particles for sustained release. Pharm. Dev. Technol. 2018, 23, 857-864. [CrossRef]

41. Oren, Z.; Shai, Y. Selective lysis of bacteria but not mammalian cells by diastereomers of melittin: Structure-function study. Biochemistry 1997, 36, 1826-1835. [CrossRef]

42. Ebbensgaard, A.; Mordhorst, H.; Overgaard, M.T.; Nielsen, C.G.; Aarestrup, F.M.; Hansen, E.B. Comparative evaluation of the antimicrobial activity of different antimicrobial peptides against a range of pathogenic Bacteria. PLoS ONE 2015, 10, e0144611. [CrossRef]

43. Galié, S.; García-Gutiérrez, C.; Miguélez, E.M.; Villar, C.J.; Lombó, F. Biofilms in the food industry: Health aspects and control methods. Front. Microbiol. 2018, 9, 898. [CrossRef]

44. Lee, B.H.; Cole, S.; Badel-Berchoux, S.; Guillier, L.; Felix, B.; Krezdorn, N.; Hébraud, M.; Bernardi, T.; Sultan, I.; Piveteau, P. Biofilm formation of listeria monocytogenes strains under food processing environments and pan-genome-wide association study. Front. Microbiol. 2019, 10, 2698. [CrossRef]

45. Flemming, H.C.; Wingender, J.; Szewzyk, U.; Steinberg, P.; Rice, S.A.; Kjelleberg, S. Biofilms: An emergent form of bacterial life. Nat. Rev. Microbiol. 2016, 14, 563-575. [CrossRef]

46. Christiansson, A.; Bertilsson, J.; Svensson, B. Bacillus cereus spores in raw milk: Factors affecting the contamination of milk during the grazing period. J. Dairy Sci. 1999, 82, 305-314. [CrossRef]

47. Čujová, S.; Bednárová, L.; Slaninová, J.; Straka, J.; Čeřovský, V. Interaction of a novel antimicrobial peptide isolated from the venom of solitary bee Colletes daviesanus with phospholipid vesicles and Escherichia coli cells. J. Pept. Sci. 2014, 20, 885-895. [CrossRef] [PubMed]

48. Zolfagharian, H.; Mohajeri, M.; Babaie, M. Bee venom (Apis mellifera) an effective potential alternative to gentamicin for specific bacteria strains-Bee venom an effective potential for bacteria. J. Pharmacopuncture 2016, 19, 225-230. [CrossRef] 
49. Navarre, W.W.; Schneewind, O. Surface Proteins of Gram-Positive Bacteria and Mechanisms of Their Targeting to the Cell Wall Envelope. Microbiol. Mol. Biol. Rev. 1999, 63, 174-229. [PubMed]

50. Baker, C.N.; Stocker, S.A.; Culver, D.H.; Thornsberry, C. Comparison of the E test to agar dilution, broth microdilution, and agar diffusion susceptibility testing techniques by using a special challenge set of bacteria. J. Clin. Microbiol. 1991, 29, 533-538. [CrossRef] [PubMed]

51. Yeaman, M.R.; Yount, N.Y. Mode of Action and Resistance Mechanisms of Antimicrobial Macrolides. Pharmacol. Rev. 2003, 55, 27-55. [CrossRef]

52. Rybak-Chmielewska, H.; Szczêsna, T. HPLC study of chemical composition of honeybee (Apis mellifera L.) venom. J. Apic. Sci. 2004, 48, 103-109.

53. ISO 1871:2009. Food and Feed Products-General Guidelines for the Determination of Nitrogen by the Kjeldahl Method. Available online: https: / / www.iso.org/standard/41320.html (accessed on 12 February 2021).

54. CLSI. Methods for Dilution Antimicrobial Susceptibility Tests for Bacteria That Grow Aerobically: Approved Standard, 10th ed.; CLSI Document M07-A10; CLSI: Wayne, PA, USA, 2015.

55. Bauer, A.W.; Kirby, W.M.M.; Tuck, M. Antibiotic susceptibility testing by a standardize disc diffusion method. Am. J. Clin. Patholagy 1966, 45, 49.

56. CLSI. Performance Standards for Antimicrobial Disk Susceptibility Tests: Approved Standard, 11th ed.; CLSI Document M02-A11; CLSI: Wayne, PA, USA, 2012.

57. R Core Team. R: A Language and Environment for Statistical Computing; R Foundation for Statistical Computing: Vienna, Austria, 2013. 